a load of 4 tons/sq. ft; but contemporary engineers, who criticized the design, said that higher loadings would have been perfectly acceptable, and would have reduced the obstruction to the waterway. The consulting engineer, Mr John Wolfe Barry, fortunately stuck to his guns; Mr Glossop said that recent boreholes near the bridge had shown that greater pressures would have been unwise. Indeed, the whole design of Tower Bridge seems to have been blessed with good fortune; the depth of the clay is only some 10 feet and, had this been penetrated, there might have been serious difficulties.

This approach is happily now of historical interest only. Settlement is frequently a source of damage to old buildings, and $\mathrm{Mr}$ Glossop quoted the example of Westminster Cathedral, where the massive tower on the north face of the cathedral has settled more than the rest of the building. Much of the progress in soil technology is due to the classical work of Terzaghi, which has been developed since 1925 into a most important branch of engineering science. The turning point, at least as far as the loading capacity of soils is concerned, seems to have come in 1942, when the foundations of a single storey building in the Firth of Forth collapsed. The design failed because it had not taken into account all the geological factors; but it provided such a mass of data for the Building Research Station to analyse that it might have been designed as a laboratory experiment. The agreement between theory and experience was so good, Mr Glossop said, that it finally brought conviction to many unbelievers.

The most marked effect of the development of soil mechanics had come in the design and construction of earth dams. In 1866, Mr Glossop said, Jacob had confidently stated that it was "idle to pursue the investigation (of earth dams) by a mathematical mode of reasoning". He suggested a three to one slope on the upstream side, and a two to one slope on the downstream side, recommendations which were accepted without question until about 1940. In 1898, two engineers attempted to justify dams on which the slope flattened progressively from top to bottom on the grounds that Mount Fujiyama was that shape. Since then, $\mathrm{Mr}$ Glossop hastened to point out, the construction of earth dams had become a much more scientific activity, a claim which he proved by reference to the Derwent Dam, built on the borders of Northumberland and County Durham, and completed in 1967.

\section{All Change at the Museums}

Sir Trrence Morrison-Scotr, Director of the British Museum (Natural History) since 1960, is to retire at the end of the year. The most important event in Sir Terence's term of office must have been the severing of the Natural History Museum from the British Museum on the passing of the British Museum Act, 1963. This meant that the Natural History Museum for the first time in its life was able to establish its own governing body of twelve trustees.

At the latest meeting of the trustees, two new appointments were also confirmed. Dr J. G. Sheals, Head of the Arachnida and Myriapoda section, is to be a deputy keeper in the Department of Zoology. Dr Sheals is particularly interested in the application of data processing equipment to the taxonomic catalogues in the museum. Another new deputy keeper-this time in the Department of Palaeontology-is to be Dr C. G.
Adams, who works on the larger species of Tertiary Foraminifera. Dr Adams will transfer from the Zoology Department to the Palaeontology Department on taking up his appointment. Both appointments are effective from April 1.

A further announcement is that Lord Radcliffe has resigned as chairman of the Board of Trustees of the British Museum because of ill-health. His place has been taken over by Lord Eccles, who will now lead in the British Museum's efforts to persuade the Government to agree to the building of the new national library next door to the present museum. Lord Eccles appears to be as vehement as Lord Radcliffe in his condemnation of the Government's action over the museum. It is understood that Lord Radcliffe will remain a trustee, at least for the time being.

\section{Science of Science}

THE Science of Science Foundation is now in the fourth year of its existence. To mark the occasion, Dr O. M. Solandt, President of the Science Council of Canada, is to give the foundation's fourth annual lecture. The foundation has continued to mount a wide ranging programme of lectures and seminars, and is now publishing a bimonthly newsletter. It has also opened a library at the University of Sussex. These developments apart, there is as yet little sign of the activities proposed in March last year when the foundation launched an appeal for $£ 282,000$ (Nature, 214, 1 and 3 ). It must be assumed that the appeal has not so far met with conspicuous success.

The foundation's newsletter (obtainable at the Ciba Foundation, 41 Portland Place, London, W1; annual subscription 2 guineas $(\$ 6)$ ) is concerned with "topics of interest in the field of the science of science". With twelve pages an issue, the newsletter contains reports of the foundation's activities and other meetings, and reviews of relevant books and pamphlets. Science policy and other news from Europe, the USA and USSR are also covered. The newsletter began as a document for internal information, but outside demand for its services has already created a small but rising circulation.

\section{Research on a Shoestring}

THe Medical Research Council of Ireland has just published its annual report for 1966 (5s.). The impoverishment of medical research in Ireland is made blatantly obvious- the council, for example, has to do without a research director or a central research institute. The reason for this appears to be to ensure that as much of the council's grant as possible goes directly to the support of research. Most of the money is used to encourage research in medical school departments, but there is also one special university unit, the Unit for Cell Metabolism in the Department of Biochemistry, University College, Dublin, and one independent unit for studying chemotherapy specially set up by the council in Trinity College. Summaries of the research carried out by these units and research in other departments supported by the council are given in the report. This research is co-ordinated by the special committees set up recently by the council to advise it on the development of particular research fields. There are five committees in all, covering cancer, cardiovascular diseases, gastroenterology and 